\title{
Regional anesthesia for pediatrics
}

\author{
Pediatrik rejyonel anestezi deneyimlerimiz
}

\author{
Hacer Şebnem Türk, ${ }^{1}$ Canan Tülay Işıl, ${ }^{1}$ Mehmet Eren Açık, ${ }^{2}$ Naim Ediz, ${ }^{1}$ \\ Pınar Sayın, ${ }^{1}$ Merih Tombul, ${ }^{3}$ Sibel Oba ${ }^{1}$ \\ ${ }^{1}$ Şişli Etfal Eğitim ve Araştırma Hastanesi Anesteziyoloji ve Reanimasyon Kliniği, İstanbul, Turkey \\ ${ }^{2}$ İstanbul Bilim Üniversitesi Anesteziyoloji ve Reanimasyon Anabilim Dal, İstanbul, Turkey \\ ${ }^{3}$ Sinop Devlet Hastanesi Anesteziyoloji ve Reanimasyon Kliniği, Istanbul, Turkey
}

\begin{abstract}
Objectives: Relevancy to regional anesthesia in pediatrics has increased, because it is complementary to general anesthesia, allows conscious postoperative analgesia without respiratory depression, technical difficulties have been defeated and new local anesthetics have been improved. Therefore we reported data of patients who underwent pediatric surgery and received regional anesthesia.

Patients and methods: We retrospectively analyzed data of all patients, who were operated in the pediatric surgery clinic of our hospital during the time period from 1.01.2012-31.12.2012 and therefore received regional anesthesia. Total amount of operations and regional anesthesia, demographic variables, regional anesthesia techniques, supportive sedatives and general anesthesia requirements, agents used for anesthesia, diagnoses and complications were recorded.

Results: In the year 2012 a total of 2,116 patients were operated in our pediatric surgery clinic and 1,196 patients (713 boys, 483 girls, mean age $5.9 \pm 4.3$ years; range 2 days to 17 years) received regional anesthesia. Caudal block was implemented in 718 patients, epidural block in 218 patients, ultrasonography (USG)-guided transversus-abdominis-plane (TAP)-block in 189 patients, USG-guided ilioinguinal-iliohypogastric block in 52 patients and spinal block in 19 patients. Average age of patients receiving caudal, epidural, TAP, ilioinguinal-iliohypogastric and spinal block was as follows: $3.1 \pm 2.3,5.4 \pm 3.1,3.6 \pm 2.8,4.4 \pm 2.6$ and $6.5 \pm 7.9$ years. Levobupivacaine $0.25 \%$ was used in 868 patients, bupivacaine $0.25 \%$ in 309 patients, heavy bupivacaine $0.5 \%$ in 19 patients. Sedation in spinal anesthesia was done with midazolam and/or propofol, the other blocks were supportive to general anesthesia. Laryngeal mask airway was inserted into 981 of the patients and 196 patients were orotracheally intubated. No other complication was observed than hematoma due to USG-guided ilioinguinal-iliohypogastric block in one patient.

Conclusion: The importance of preventing postoperative pain should be considered in pediatrics and therefore advantage of regional anesthesia techniques should be taken. As far as differences in anatomy, physiology, pharmacology are well known, regional anesthesia is safe to apply in pediatrics.
\end{abstract}

Keywords: Pediatrics; postoperative analgesia; regional anesthesia.

\section{öz}

Amaç: Rejyonel tekniklerin genel anesteziyi tamamlayıcı bir yöntem olarak düşünülmesi, bilinci ve solunumu etkilemeden ameliyat sonrası analjezi sağlaması, teknik güçlüklerin aşılması, yeni lokal anesteziklerin gelişimi pediatrik hastalarda rejyonel anesteziye ilgiyi artırmıştır. Bu nedenle pediatrik cerrahi geçiren ve rejyonel anestezi uygulanan hastalarımızın verilerini sunduk.

Hastalar ve yöntemler: 1.01.2012-31.12.2012 tarihleri arasında hastanemiz çocuk cerrahisi kliniğinde ameliyat edilen ve rejyonel anestezi uygulanan tüm hastaların verileri geriye dönük incelendi. Toplam ameliyat ve rejyonel anestezi sayısı, demografik verileri, rejyonel anestezi teknikleri, destekleyici sedatif ve genel anestezi gereksinimleri, anestezi için kullanılan ajanları, tanıları ve komplikasyonları kaydedildi.

Bulgular: 2012 yılında çocuk cerrahisi kliniğinde 2116 hasta ameliyat edildi, 1196 hastaya (713 erkek, 483 kız, ort yaş $5.9 \pm 4.3$ yıl; dağılım 2 gün- 17 yıl) rejyonel anestezi uygulandı. 718 hastaya kaudal blok, 218 hastaya epidural anestezi, 189 hastaya ultrasonografi (USG)-güdümlü transversusabdominis-düzlem (TAP) blok, 52 hastaya USG-güdümlü ilioinguinal-iliohipogastrik blok, 19 hastaya spinal anestezi uygulandı. Kaudal blok, epidural anestezi, TAP blok, ilioinguinal-iliohipogastrik blok ve spinal anestezi uygulanan hastaların yaş ortalaması sırasıyla 3.1 $\pm 2.3,5.4 \pm 3.1,3.6 \pm 2.8,4.4 \pm 2.6$ ve $6.5 \pm 7.9$ yıl idi. 868 hastada \%0.25'lik levobupivakain, 309 hastada \%0.25'lik bupivakain, 19 olguda \%0.5'lik ağır bupivakain kullanıldı. Spinal anestezi uygulanan hastalarda midozolam veya propofol ile sedasyon uygulanmıştı diğer tüm hastalarda genel anestezi uygulanmıştı. 981 hastaya larengeal maske takıldı ve 196 hasta orotrakeal entübe edildi. Ultrasonografi-güdümlü ilioinguinal-iliohipogastrik blok yapılan bir hastada hematom gelişmesi dışında komplikasyonla karşılaşılmadı.

Sonuç: Çocuk hastalarda da ameliyat sonrası ağrının engellenmesinin önemi unutulmamalı, bu amaçla rejyonel tekniklerden faydalanılmalıdır. Pediatrik olguların anatomik, fizyolojik, farmakolojik farklılıkları bilinerek güvenle rejyonel anestezi uygulanabilir.

Anahtar sözcükler: Pediatrik; ameliyat sonrası analjezi; rejyonel anestezi.

Received: August 23, 2015 Accepted: September 22, 2015

Correspondence: Hacer Şebnem Türk, MD. Şişli Etfal Eğitim ve Araştırma Hastanesi Anesteziyoloji ve Reanimasyon Kliniği, 34360 Şişli, İstanbul, Turkey

Tel: +90 212 - 2312209 / 5414 e-mail: hacersebnem@yahoo.com.tr 
Regional nerve blockade for anesthesia and analgesia in pediatrics is almost one-hundred years old. In the 1980's a lot of advantages of regional anesthesia were realized and physicians became aware of the requirement for treating pain in children. Nowadays it is well known, that children respond to surgical stress and feel as much pain as adults do. That's why pain has to be prevented and treated, preferably without depression of the respiratory center. Relevancy to regional anesthesia in pediatrics has increased, because it is complementary to general anesthesia considering reduced analgesic requirements and providing better postoperative pain control. Besides it allows conscious postoperative analgesia without respiratory depression. Along with the development of technology, difficulties in special equipment for pediatrics have been defeated. In the medical field, new local anesthetics have been improved and studies demonstrated their safety in pediatric applications. ${ }^{[1,2]}$ One shut or continuous drug administration via regional anesthesia, reduces general anesthetic drug requirements, provides better postoperative pain control and decreases adverse effects of general anesthetics. ${ }^{[3]}$

We conducted this study to attract attention to pediatric regional anesthesia and it's importance. Therefore we retrospectively analyzed data of patients who underwent surgery in our pediatric surgery clinic and received regional anesthesia.

\section{PATIENTS AND METHODS}

Records of all pediatric patients who were operated in our pediatric surgery clinic in the year 2012 were evaluated retrospectively. Data of patients who received regional anesthesia were included in this study. Demographic variables, regional anesthesia technique, local anesthetic agent, adjuvant drugs, general anesthesia support or sedation were recorded.

Table 1. Demographic data of patients receiving regional anesthesia

\begin{tabular}{lcr}
\hline & $n$ & Mean \pm SD \\
\hline Age (years) & & $5.9 \pm 4.3$ \\
Operated patients & 2,116 & \\
Operation account & 3,258 & \\
Patients receiving regional anesthesia & 1,196 & \\
Gender & & \\
$\quad$ Boys & 713 & \\
$\quad$ Girls & 483 & \\
\hline SD. Standard deviation & &
\end{tabular}

\section{Statistical analysis}

Statistical analysis was performed using the SPSS version 15.0 for Windows software program (SPSS Inc., Chicago, IL, USA). Data were presented as mean \pm standard deviation (Mean \pm SD).

\section{RESULTS}

In the one year time period of 2012, totally 2,116 patients underwent 3,258 operations and 1,196 patients (713 boys, 483 girls, mean age $5.9 \pm 4.3$ years; range 2 days to 17 years) received regional anesthesia (Table 1).

Caudal block was implemented in 718 patients, epidural block in 218 patients, ultrasonography (USG)-guided transversus-abdominis-plane (TAP)block in 189 patients, USG-guided ilioinguinaliliohypogastric block in 52 patients and spinal block in 19 patients (Figure 1).

Mean age of patients receiving caudal block $(\mathrm{n}=718)$ was $3.1 \pm 2.3$ years, 465 were boys and 253 were girls. 247 patients underwent hypospadias, 215 bilateral inguinal hernia, 157 undescended testes+circumcision, 58 unilateral inguinal hernia operations. Levobupivacaine $0.25 \%$ was injected to 477 patients, bupivacaine $0.25 \%$ to 241 patients and fentanyl as adjuvant to 55 patients. All patients received general anesthesia with respiratory support via laryngeal mask airway (LMA). Anesthesia induction was done with sevoflurane in 238 patients and with intravenous injection in 480 patients (Table 2).

Mean age of patients receiving epidural block $(n=218)$ was $5.4 \pm 3.1$ years, 88 were boys and 130 were girls. 81 patients were operated because of anorectal malformation, 50 because of vesicoureteric-reflux, 39 because of Hirschsprung disease, 17 because of ileus, 17 because

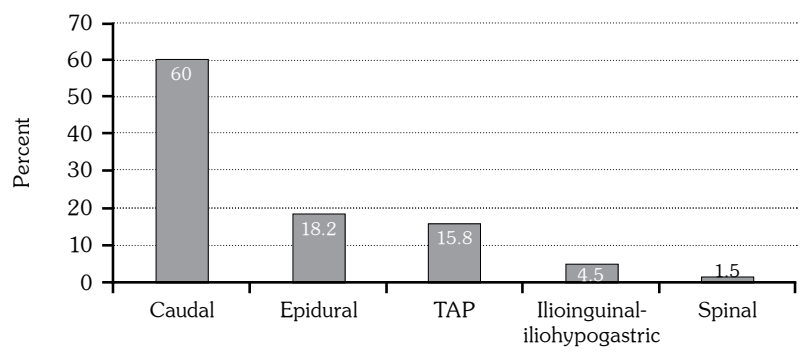

Figure 1. Regional anesthesia technique distributions. TAP: Transversus-abdominis-plane. 
Table 2. Regional anesthesia techniques and perioperative data

\begin{tabular}{|c|c|c|c|c|c|c|c|c|c|c|}
\hline & \multicolumn{2}{|c|}{ Caudal } & \multicolumn{2}{|c|}{ Epidural } & \multicolumn{2}{|r|}{ TAP } & \multicolumn{2}{|c|}{$\begin{array}{l}\text { Ilioinguinal- } \\
\text { iliohypogastric }\end{array}$} & \multicolumn{2}{|r|}{ Spinal } \\
\hline & $\mathrm{n}$ & Mean \pm SD & $\mathrm{n}$ & Mean \pm SD & $\mathrm{n}$ & Mean \pm SD & $\mathrm{n}$ & Mean \pm SD & $\mathrm{n}$ & Mean \pm SD \\
\hline Age (years) & & $3.1 \pm 2.3$ & & $5.4 \pm 3.1$ & & $3.6 \pm 2.8$ & & $4.4 \pm 2.6$ & & $6.5 \pm 7.9$ \\
\hline \multicolumn{11}{|l|}{ Gender } \\
\hline Boys & 465 & & 88 & & 119 & & 33 & & 8 & \\
\hline Girls & 253 & & 130 & & 70 & & 19 & & 11 & \\
\hline Heavy bupivacaine $0.5 \%$ & - & & - & & - & & - & & 19 & \\
\hline Levobupivacaine $0.25 \%$ & 477 & & 179 & & 171 & & 41 & & - & \\
\hline Bupivacaine $0.25 \%$ & 241 & & 39 & & 18 & & 11 & & - & \\
\hline Adjuvan (Fentanyl) & 55 & & 117 & & - & & - & & - & \\
\hline General anesthesia & 718 & & 218 & & 189 & & 52 & & - & \\
\hline Sedation & - & & - & & - & & - & & 19 & \\
\hline Mask anesthesia induction & 238 & & 83 & & 88 & & 19 & & - & \\
\hline Intravenous anesthesia induction & 480 & & 135 & & 101 & & 33 & & 19 & \\
\hline
\end{tabular}

TAP: Transversus-abdominis-plane; SD: Standard deviation.

of bilateral inguinal hernia, five because of over cyst, two because of neuroblastoma and one because of Wilm's tumor. Eight patients underwent thoracotomy because of varied diagnoses and were placed a thoracal-epiduralcatheter. Levobupivacaine $0.25 \%$ was injected to 179 patients, bupivacaine $0.25 \%$ to 39 patients and fentanyl as adjuvant to 117 patients. An epidural catheter was placed into 152 patients and 66 patients received one-shut medication. All patients received general anesthesia, 22 patients were placed a LMA and 196 were orotracheally intubated. Anesthesia induction was done with sevoflurane in 83 patients and with intravenous injection in 135 patients (Table 2).

Mean age of patients receiving USG-guided TAP-block $(\mathrm{n}=189)$ was $3.6 \pm 2.8$ years, 119 were boys and 70 were girls. 107 patients underwent unilateral inguinal hernia, 31 undescended testes, 29 hydrocele and 22 acute appendicitis operations. Levobupivacaine $0.25 \%$ was injected to 171 patients and bupivacaine 0.25\% to 18 patients. All patients received general anesthesia with respiratory support via LMA. Anesthesia induction was done with sevoflurane in 88 patients and with intravenous injection in 101 patients (Table 2).

Mean age of patients receiving USG-guided ilioinguinal-iliohypogastric block $(\mathrm{n}=52)$ was $4.4 \pm 2.6$ years, 33 were boys and 19 were girls. Twenty-seven patients underwent unilateral inguinal hernia, 15 unilateral undescended testes and 10 hydrocele operations. Levobupivacaine $0.25 \%$ was injected to 41 patients and bupivacaine $0.25 \%$ to 11 patients. All patients received general anesthesia with respiratory support via LMA. Anesthesia induction was done with sevoflurane in 19 patients and with intravenous injection in 33 patients (Table 2 ).

Mean age of patients receiving spinal anesthesia $(n=189)$ was $6.5 \pm 7.9$ years ( 2 days -17 years old), eight were boys and 11 were girls. Eight patients were operated because of pilonidal sinus, seven because of inguinal hernia, three because of pyloric stenosis and one because of undescended testes. Bupivacaine $0.5 \%$ was injected to all patients and no adjuvant drug was combined. All patients received midazolam and/or propofol sedation (Table 2).

No other complication was observed than hematoma due to USG-guided ilioinguinaliliohypogastric block in one patient.

\section{DISCUSSION}

Regional anesthesia techniques, which can also be applied to newborns and infants have widespread advantages. However they need to be performed by specialists. Different regional anesthesia techniques can be used separately or combined with general anesthesia, which is more common. Their importance relies on effective pain control in the perioperative and postoperative period. Untreated pain causes dysfunctions in autonomic, hormonal, metabolic, immunologic and behavioral systems. ${ }^{[4]}$

Considering that metabolization of general anesthetic drugs in newborns and infants is still unclear, regional anesthesia reduces their consumption, provides hemodynamical stability 
and reduces hospital stay, consequently costs. Especially since the USG has become a routine additional guide in regional blocks, safety in regional anesthetic techniques has increased..$^{[5]}$

Today, caudal anesthesia is commonly used, because it is easy to practice and provides effective analgesia during the intraoperative and postoperative period. Even one shut of medication injected via caudal block in pediatrics reduces intraoperative anesthetic and opioid requirements during surgery located under the diaphragm. It has important advantages as well as painless patient follow-up and shorter hospital stay. ${ }^{[6]}$ According to Sanders ${ }^{[7]} 61.5 \%$ of central blocks applied to pediatrics and 49.5\% of all central blocks consist of caudal blocks. There are not enough comparative studies evaluating epidural anesthesia in pediatric patients. Wilson et al. ${ }^{[8]}$ conducted a retrospective study to determine outcomes of epidural and intravenous opioid analgesia following Nissen fundoplication and the results indicated that epidural analgesia might be associated with improved outcome as shorter postoperative care unit admission and shorter total hospital stay. Since there are not very much studies in pediatrics, conducted in adults, the MASTER study was one of the most comprehensive studies involving epidural anesthesia and demonstrated that respiratory complications were fewer in epidural anesthesia. ${ }^{[9]}$ Other studies showed that pain control was provided easier and better in epidural anesthesia and nausea-vomiting incidence was also fewer. ${ }^{[10,11]}$ Despite of all these benefits, a study designed in England showed that the pediatric epidural practice decreased $40 \%$ in the years 2006-2011, which might be related to increased laparoscopic surgery and development of different regional nerve blocks. Additionally, frequency of complications in epidural anesthesia were 1:2,000, serious and permanent complication frequency was $1: 10,000$, but in caudal anesthesia this ratio was $2: 100,000 .{ }^{[12]}$ Because of this reason pro and contra should be thought well and if the surgical procedure is relevant caudal anesthesia should be preferred. ${ }^{[12]}$

Morrison et al. ${ }^{[13]}$ conducted a survey on urologists to assess their suggestions on postoperative pain control. Ninety percent of the participants preferred regional anesthesia techniques, $19 \%$ epidural and $42 \%$ caudal blocks.

Beyaz et al. ${ }^{[14]}$ retrospectively evaluated their regional anesthesia experience in pediatric patients from 2005 to 2009. A total of 2,200 children were analyzed. Of all regional anesthesia types 94\% were caudal blocks, $3 \%$ were spinal blocks, $2 \%$ were lumbar epidural blocks and $1 \%$ was penile block. They remarked that caudal anesthesia was the most frequently performed regional anesthesia type. The same authors analyzed their local anesthetic choices and consumptions for caudal anesthesia in another study contenting 2,088 patients. ${ }^{[15]}$ Levobupivacaine was used in 79.9\%, bupivacaine in $20.1 \%$ and adjuvant agents in $2.5 \%$. Furthermore proseal LMA was applied in $48.2 \%$ of the patients.

A survey to assess pediatric regional anesthesia practice of anesthesiologists working in the United Kingdom was done in 2002. Ninety-six percent of the respondents to the questionnaires used caudal anesthesia and $72 \%$ used caudal, epidural and peripheric blocks. Fifty-eight percents of them used adjuvants with local anesthetics in caudal block, the most being fentanyl with $21 \%$, clonidine $26 \%$, diamorphine $13 \%$ and ketamine $32 \% .{ }^{[7]}$ According to our results regional anesthesia is used in a frequency of $56.5 \%$. These are to $60 \%$ caudal blocks, $18.2 \%$ are epidural blocks, $15.8 \%$ are TAP blocks, $4.5 \%$ are ilioinguinaliliohypogastric blocks and $1.5 \%$ are spinal blocks. Adjuvants in our clinic were used in $14.3 \%$ of patients and $72.5 \%$ were levobupivacaine $0.25 \%$, $25.8 \%$ were bupivacaine $0.25 \%$. Ninety-eight percent received general anesthesia and a LMA was inserted into $82 \%$. Complication frequency was $0.08 \%$.

Central neuraxial blocks, like caudal or epidural blocks, which are preferred in children for pain control may be contraindicated in patients having bleeding disorders, spinal dystrophy, laminectomy, fusion after spinal instrumentation or anatomic pathologies concerning the bones. In such patients, opioid analgesia is unavoidable, postoperative nausea and vomiting can occur more often, compared to regional anesthesia techniques. Besides opioid analgesia can cause hypoventilation in the postoperative period especially in infants. ${ }^{[16]}$ The tendency is sliding 
from central neuraxial blocks to peripheral nerve blocks. To provide advanced pain control in infants and children, the USG-guided TAP block seems to be a good alternative. ${ }^{[17]}$ Another option is the ilioinguinal-iliohypogastric block, which is especially preferred in unilateral inguinal hernia operations. However, the handicap in this block type is, that it is not effective in pain control at the peritoneum and spermatic cord and also is difficult to apply. When this block is done with the Landmark technique, only 14\% of the local anesthetic is successfully distributed, that's why it is performed under USG guidance. ${ }^{[17]}$ Besides it has limitations in usage in newborns and infants, because higher local anesthetic doses are required. ${ }^{[18]}$ But controlled trials proved this type of regional block to provide enough and successful analgesia in especially inguinal blocks, where postoperative hospital stay and nauseavomiting decreased. ${ }^{[19]}$

Transversus-abdominis-plane block is a simple, safe, efficient and alternative regional anesthesia type for postoperative analgesia in abdominal surgery. The point in this block is that the innervation of the abominal wall is coming from the transversus abdominis fascial plane and therefore this block is very efficient and reduces analgesic requirements. ${ }^{[20]}$ Transversusabdominis-plane block was compared to epidural and infiltration anesthesia and it was as efficient as the other blocks. ${ }^{[21]}$ Unfortunately, there are not enough studies comparing TAP block to other analgesic techniques. ${ }^{[17,20,21]}$ Together with the USG-guided regional anesthesia applications, complication incidences decreased. ${ }^{[22]}$ Although there are not very much studies about the TAP block in pediatrics, some authors indicated that TAP block reduced postoperative analgesic consumption. ${ }^{[16,23]}$ Suresh and Chan ${ }^{[16]}$ underlined that anatomical structures could not be seen in USG in pediatric patient as well as in adults and that because of that TAP block failure was higher. Spinal anesthesia is easy to perform and an efficient method. Sedation during the procedure and afterwards is required in children. Complication frequency is lower than in adults. No hemodynamical changes occur. However its duration is shorter. Spinal anesthesia was preferred in newborns with apnoea risk before, but today a lot of centers have increased spinal anesthesia experience in different ages. ${ }^{[24]}$ At the
Kuopio University in Finland authors declared that they had a spinal anesthesia practice in pediatrics about 1,000 patients, and that they did not preferred spinal anesthesia in newborns with weight under $5 \mathrm{~kg}$, because of difficulties in practice and to protect them of local anesthetic toxicity. ${ }^{[24]}$

There are pharmacodynamical and pharmacokinetical differences in children and adults. Maximum confidential doses should be known well. Local anesthetic distribution volume in children is higher. Pseudocholinesterase and albumin level is lower in infants younger than six months. Because of this reason higher doses of local anesthetics are required and this results with prolonged effects and increased risk of toxicity. ${ }^{[25]}$

A network study evaluating 13,725 pediatric patients in the years 2007-2010 reported 14,917 regional blocks without any serious complications or death. Complication ratios were lower in one shut drug injections and USG-guided procedures. ${ }^{\text {[26] }}$

In conclusion, pediatric regional techniques are practiced with an incidence of $56.5 \%$ in our clinic. Caudal block is the most preferred regional anesthesia technique. Regional anesthesia techniques can be practiced on pediatrics safely for perioperative and postoperative analgesia.

\section{Declaration of conflicting interests}

The authors declared no conflicts of interest with respect to the authorship and/or publication of this article.

\section{Funding}

Financial support was provided by departmental sources.

\section{REFERENCES}

1. Anand KJ, Carr DB. The neuroanatomy, neurophysiology, and neurochemistry of pain, stress, and analgesia in newborns and children. Pediatr Clin North Am 1989;36:795-822.

2. Tobias JD. Postoperative pain management. Pediatr Ann 1997;26:490-500.

3. Suresh S, Birmingham PK, Kozlowski RJ. Pediatric pain management. Anesthesiol Clin 2012;30:101-17.

4. Polaner DM, Drescher J. Pediatric regional anesthesia: what is the current safety record? Paediatr Anaesth 2011;21:737-42. 
5. Bosenberg A. Benefits of regional anesthesia in children. Paediatr Anaesth 2012;22:10-8.

6. Silvani P, Camporesi A, Agostino MR, Salvo I. Caudal anesthesia in pediatrics: an update. Minerva Anestesiol 2006;72:453-9.

7. Sanders JC. Paediatric regional anaesthesia, a survey of practice in the United Kingdom. Br $\mathrm{J}$ Anaesth 2002;89:707-10.

8. Wilson GA, Brown JL, Crabbe DG, Hinton W, McHugh $\mathrm{PJ}$, Stringer MD. Is epidural analgesia associated with an improved outcome following open Nissen fundoplication? Paediatr Anaesth 2001;11:65-70.

9. Rigg JR, Jamrozik K, Myles PS, Silbert B, Peyton $\mathrm{P}$, Parsons RW, et al. Design of the multicenter Australian study of epidural anesthesia and analgesia in major surgery: the MASTER trial. Control Clin Trials 2000;21:244-56.

10. Block BM, Liu SS, Rowlingson AJ, Cowan AR, Cowan JA Jr, Wu CL. Efficacy of postoperative epidural analgesia: a meta-analysis. JAMA 2003;290:2455-63.

11. Guay J. The benefits of adding epidural analgesia to general anesthesia: a metaanalysis. $\mathrm{J}$ Anesth 2006;20:335-40.

12. Llewellyn N, Moriarty A. The national pediatric epidural audit. Paediatr Anaesth 2007;17:520-33.

13. Morrison K, Herbst K, Corbett S, Herndon CD. Pain management practice patterns for common pediatric urology procedures. Urology 2014;83:206-10.

14. Beyaz SG, Tokgöz O, Tüfek A. Regional anaesthesia in paediatric surgery: results of 2200 children. J Pak Med Assoc 2011;61:782-6.

15. Beyaz SG, Tokgöz O, Tüfek A. Caudal epidural block in children and infants: retrospective analysis of 2088 cases. Ann Saudi Med 2011;31:494-7.

16. Suresh S, Chan VW. Ultrasound guided transversus abdominis plane block in infants, children and adolescents: a simple procedural guidance for their performance. Paediatr Anaesth 2009;19:296-9.
17. Willschke H, Kettner S. Pediatric regional anesthesia: abdominal wall blocks. Paediatr Anaesth 2012;22:88-92.

18. Lee S, Tan JS. Ultrasonography-guided ilioinguinaliliohypogastric nerve block for inguinal herniotomies in ex-premature neonates. Singapore Med J 2013;54:218-20.

19. Bærentzen F, Maschmann C, Jensen K, Belhage B, Hensler M, Børglum J. Ultrasound-guided nerve block for inguinal hernia repair: a randomized, controlled, double-blind study. Reg Anesth Pain Med 2012;37:502-7.

20. McDonnell JG, O'Donnell B, Curley G, Heffernan A, Power C, Laffey JG. The analgesic efficacy of transversus abdominis plane block after abdominal surgery: a prospective randomized controlled trial. Anesth Analg 2007;104:193-7.

21. Kadam VR, Moran JL. Epidural infusions versus transversus abdominis plane (TAP) block infusions: retrospective study. J Anesth 2011;25:786-7.

22. Aissou M, Ghalayini M, Yazid L, Abdelhalim Z, Dufeu N, Beaussier M. Ultrasound control of local anaesthetic location after TAP block performed using landmark-based technique: a cohort study. Ann Fr Anesth Reanim 2011;30:641-4. [Abstract]

23. Carney J, Finnerty O, Rauf J, Curley G, McDonnell JG, Laffey JG. Ipsilateral transversus abdominis plane block provides effective analgesia after appendectomy in children: a randomized controlled trial. Anesth Analg 2010;111:998-1003.

24. Kokki H. Spinal blocks. Paediatr Anaesth 2012;22:56-64.

25. Mazoit JX. Local anesthetics and their adjuncts. Paediatr Anaesth 2012;22:31-8.

26. Polaner DM, Taenzer AH, Walker BJ, Bosenberg A, Krane EJ, Suresh S, et al. Pediatric Regional Anesthesia Network (PRAN): a multi-institutional study of the use and incidence of complications of pediatric regional anesthesia. Anesth Analg 2012;115:1353-64. 